\title{
Investigation The Effect of Chitosan Coating and Temperature Storage to Extend The Shelf Life Zalacca (Salacca zalacca)
}

\author{
Santosa $^{\#}$, Omil Charmyn Chatib ${ }^{\#}$, Khandra Fahmy ${ }^{\#}$, Fadillah Artika ${ }^{\#}$ \\ \# Department of Agricultural Engineering, Faculty of Agricultural Technology, Andalas University, Padang, 25163, Indonesia \\ E-mail: santosa764@yahoo.co.id
}

\begin{abstract}
The aimed of this research was to extend the shelf life of zalacca by investigation the effects of chitosan coating and storage-temperature. Fruits were coated with chitosan at concentration $0.5 \%, 1 \%, 1.5 \%$ and $0 \%$ as control and then were stored at temperature $15^{\circ} \mathrm{C}$ and room temperature. The result of this research shows that coating with concentration $0.5 \%$ at $15^{\circ} \mathrm{C}$ was the best condition to extend the shelf life of zalacca compared to concentration $1 \%, 1,5 \%$ and control. In this condition, the fruit could be stored until day 24. By coating zalacca fruit with chitosan influenced the total soluble content, however, it did not affect to the value weight loss, hardness, water content, and vitamin $\mathrm{C}$ of fruit.
\end{abstract}

Keywords - Zalacca; edible coating; chitosan; shelf life

\section{INTRODUCTION}

Zalacca (Salacaazalacca) is a kind of Indonesia tropical fruit, which has been fond by the people because of its special taste. Zalacca consists of mineral and the lots of nutrients, which are useful for human health. There are many varieties of zalacca growing in Indonesia such as Pondoh, Condet, Bali, Madu, Sidempuan, and Pasaman. In WestSumatera this fruit produces in Gunungc Tuleh Sub district, Pasaman Regency which develops as local variety. The production of zalacca in West Sumatera has increased since the its field growing up, achieved 46.13 ha with total production 543.42 ton [1]. Zalacca is belongs to nonclimacteric and harvesting if it ripes on the tree. The respiration of zalacca decreased indicated that $\mathrm{CO}_{2}$ not increased significantly after harvest. Zalacca is perishable commodities and have short-aging. In general, zalacca can be stored for \pm 7 days at room temperature, and it will be prolonged at low temperature. Titiek and Mudjisihono [2] have been reported that the optimal temperature for storage of zalacca was $15^{\circ} \mathrm{C}$.

For maintaining the quality of agricultural product is required proper postharvest handling. As for zalacca, storage without any treatment causes damage and short the self life. One of technology for maintaining quality is edible coating by using chitosan which can be used for preserving quality of fruit. Some of the research has been showed that chitosan is potential as precipitation for the fruit.

Edible coatings are being used to improve food appearance and conservation due to their environmentally friendly nature. They act as barriers to moisture and oxygen during processing, handling, and storage, thus retarding food deterioration. Also, they improve safety, due to their natural biocide activity or to the incorporation of anti-microbial compounds [3]. Guerreiro [4] also reported that coating of raspberry maintains the quality in aspect storage ability, nutrional, and sensor quality. Forato also reported that edible coating extend the self-life fresh and cut guava. However, there are limited information for storage of zalacca in order to extend the self-life and maintaining the quality.

The aim for this research was to develop a simply technology to increase and maintain the quality and then to length the life of its storing with the layer of chitosan until it guaranteed the marketed zalacca.

\section{MATERIALS AND METHODS}

\section{A. Materials and Tool}

Local zalaccas (Salacca zalacca) were used in this study shown in Figure $1.75 \mathrm{~kg}$ fruits were weighed using for each concentration with three replicants. Chitosan was made from shrimp skin about $100 \mathrm{~g}$, acetate acid $1 \%$, aquades, iod $0,01 \mathrm{~N}$ and amilum. The instruments used in this study were thermometer to measure temperature, hygrometer to measure relative humidity, digital force gauge to measure the hardness of fruit, hand refrectometer to measure the total soluble of solution, magnetic stirrer to cook chitosan, refrigerator, digital oven, aluminium grail, buret, glass of measuring, cup, and Erlenmeyer. 


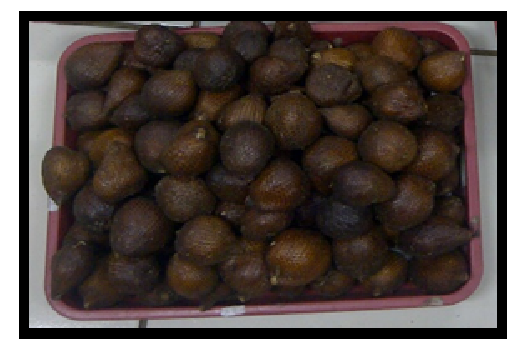

Fig. 1 The Local Variety of Zalacca

\section{B. Research Plan}

The data was solved by using anova two factorials with three replicants. The factors were temperature storage (room temperature and $15^{\circ} \mathrm{C}$ ) and layer of chitosan concentration $(0,5 \%, 1 \%, 1,5 \%$ and control).

Factor A, storage temperature

$$
\begin{gathered}
a_{1}=\text { room temperature }\left( \pm 28{ }^{0} \mathrm{C}\right) \\
a_{2}=\text { temperature } 15{ }^{\circ} \mathrm{C}
\end{gathered}
$$

Factor B, concentration of chitosan:

$$
\begin{aligned}
& b_{0}=\text { control } \\
& b_{1}=\text { layer of chitosan } 0.5 \% \\
& b_{2}=\text { layer of chitosan } 1 \% \\
& b_{2}=\text { layer of chitosan } 1.5 \%
\end{aligned}
$$

\section{Research Implementation}

Zalacca was bought from the farmer in GunungTuleh Sub district, Pasaman Barat Regency. After harvesting, fruits were put at the box to prevent from the friction and collision during transportation to Laboratory. The fruit was washed from spine and any wastes. Three comparison of chitosan layer were used i.e. chitosan; acetate acid 1\%) (height/volume) which was different 0.5: 1000, 1: 100, and 1.5: 100) [5]. The process of making chitosan solution with concentration $0,5 \%$ was made by scaling chitosan with $5 \mathrm{~g}$ and then it was dissolved with $1 \%$ acetate acid $(100 \mathrm{ml})$ then heated at $40^{\circ} \mathrm{C}$ for 30 minutes. Then it mixed by using stirrer, and added by aquades until volume reached $1000 \mathrm{ml}$ which made the solution become flat. The same treatment could be done to make chitosan solution with $1 \%$ and $1,5 \%$ concentration. For $1 \%$ concentration, $10 \mathrm{~g}$ chitosan was used and for $1,5 \%$ concentration used $15 \mathrm{~g}$ of chitosan. The zalacca were dipped in the edible coating for $30 \mathrm{~s}$ and then dried, and then stored at $15^{\circ} \mathrm{C}$ and at $28^{\circ} \mathrm{C}$.

\section{Quality Parameters}

The observation of fruit quality was conducted on day 0,1 , 2, 3 and until fruit damaged. with characteristics such as a wound, bruised, a skin cracking, smell, soft texture, and a bad texture. The quality parameters such as height shrinking, hardness, and content of water, amount of soluble solid, vitamin $\mathrm{C}$, temperature, relative humidity, and organoleptic testing were evaluated.

\section{RESULTS AND DISCUSSION}

\section{A. Weight loss}

The weight loss of zalacca was measured by using digital weigher. The weight loss of zalacca is shown at Figure 2 and Figure 3.

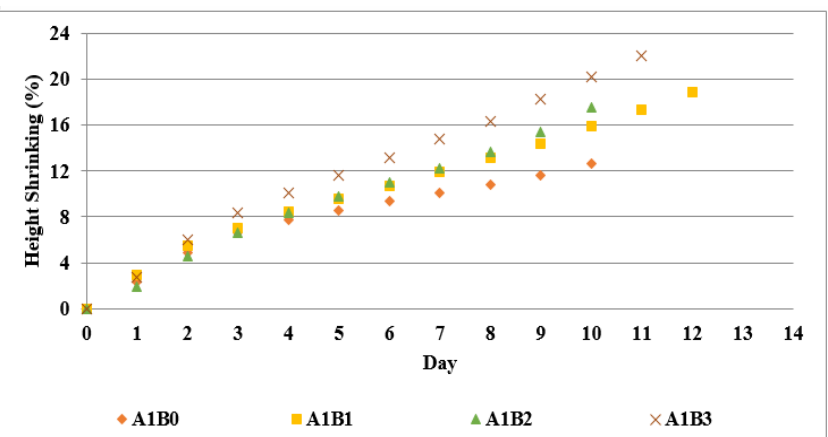

Fig. 2 Weight loss of zalacca coating at different chitosan concentration and stored at room temperature

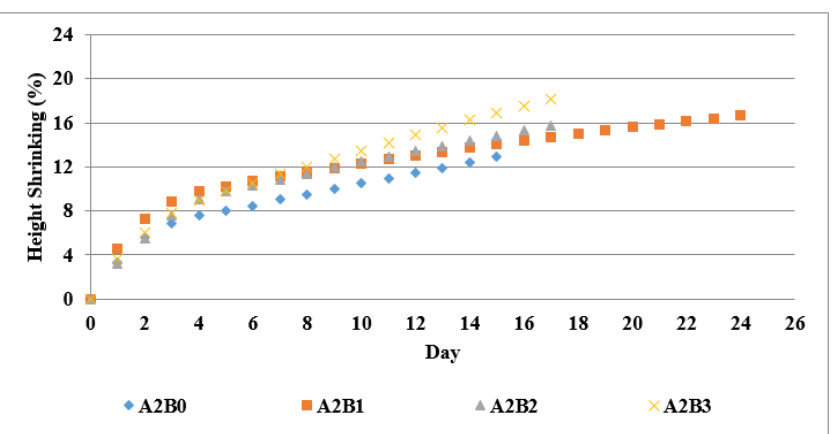

Fig. 3 The Weight loss of zalacca coating at different chitosan concentration and stored at $15^{\circ} \mathrm{C}$.

Based on the observation show that the weight shrinking of zalacca for all the treatment at various temperatures and chitosan concentration was increased every day. In Figure 2 show that zalacca coating at chitosan concentration $1.5 \%$ and stored (A1B3) the weight loss increased mostly on the first day around $2.775 \%$ and on the last day of storage became $22.028 \%$. While, coating concentration $1 \%$ and stored at room temperature (A1B2) the weight loss on day 1 was $1.901 \%$ and increased to $17.556 \%$ on day 10. The weight loss of zalacca coating at $0.5 \%$ concentration (A1B1) was smaller than concentration $1 \%$ and $1.5 \%$. The value of weight loss at concentration $0.5 \%$ was $2.973 \%$ on day 1 and it increased to $18.912 \%$ on day 12 . Zalacca without the layer stored at room temperature (A1B0) the increasing of weight loss was smaller compared to chitosan, but could be stored only10 days.

The weight loss of zalacca stored at $15^{\circ} \mathrm{C}$ was smaller than room temperature. In Figure 3 , shows that at $15^{\circ} \mathrm{C}$ the weight shrinking was not different for all treatment during period of storage. The highest weight shrinking was shows at chitosan layer $1.5 \%$ (A2B3). The weight loss on was $3.623 \%$ and increased to $18.157 \%$ on day 17 . The weight shrinking of zalacca at $1 \%$ (A2B2) was not different compared with concentration $1.5 \%$. The weight shrinking of zalacca at concentration $1 \%$ on the first of storage was $3.234 \%$ and increased $\mathrm{t} 15.769 \%$ on 17 day of storage. The decreasing of weight loss at $0.5 \%$ at $15^{\circ} \mathrm{C}$ (A2B1) was smallest compared at concentration $1 \%$ and $1.5 \%$. The weight loss of zalacca at $0,5 \%$ was not different without the layer. Then, the chitosan layer at concentration $0.5 \%$ was best concentration compared with concentration $1 \%$ and $1.5 \%$. The weight shrinking of zalacca at chitosan layer $0.5 \%$ at the first storage was $4.579 \%$ and increased to $15.473 \%$ on $24^{\text {th }}$ day of storage. The weight loss of zalacca without layer was 
$3.309 \%$ and increased to $16.700 \%$ on $15^{\text {th }}$ day of storage. Similar result was found in raspberry with edible coating [4]. The weight loss increased through storage time in all treatments. However, the increase was higher in edible coatings than in control. Nevertheless, from our study control had short shelf life compared with fruit stored with edible coating. Edible coating with chitosan $0.5 \%$ stored at $15{ }^{\circ} \mathrm{C}$ was the best layer because it could be stored zalacca for 24 days. The statistical analysis of height shrinking of zalacca was shown in Table 1. The weight loss occurs because after the fruit harvest it has a natural tendency for weight loss, mainly by transpiration process [6].

TABLE I

ANALYSIS OF ANOVA FOR WeIGHT LOSS OF ZALACCA

\begin{tabular}{|c|c|c|c|c|c|c|}
\hline Source & $\begin{array}{l}\text { Type III } \\
\text { Sum of } \\
\text { Squares }\end{array}$ & df & $\begin{array}{l}\text { Mean } \\
\text { Square }\end{array}$ & F & Sig. & Conclusion \\
\hline $\begin{array}{l}\text { Concentration } \\
\text { of Chitosan }\end{array}$ & 51,279 & 3 & 17,093 & 1,652 & 0,217 & NS \\
\hline Temperature & 2,667 & 1 & 2,667 & 0,258 & 0,619 & NS \\
\hline $\begin{array}{c}\text { Concentration } \\
\text { of Chitosan } \times \\
\text { Temperature }\end{array}$ & 4,208 & 3 & 1,403 & 0,136 & 0,937 & NS \\
\hline Error & 165,582 & 16 & 10,349 & & & \\
\hline Total & 223,736 & 23 & & & & \\
\hline
\end{tabular}

From statistical shows that the significant value of chitosan concentration was 0.217 , it means that there was not difference in weight shrinking of zalacca. From storage temperature, it was not different toward the weight loss of zalacca.

\section{B. Hardness}

The hardness of zalacca was measured by using digital force gauge FGS-5S with diameter of probe $0.0055 \mathrm{~m}$ and the wide of area $\left(\mathrm{m}^{2}\right) 0,0000301754$. Figure 4 and 5 hardness of zalacca at each treatment.

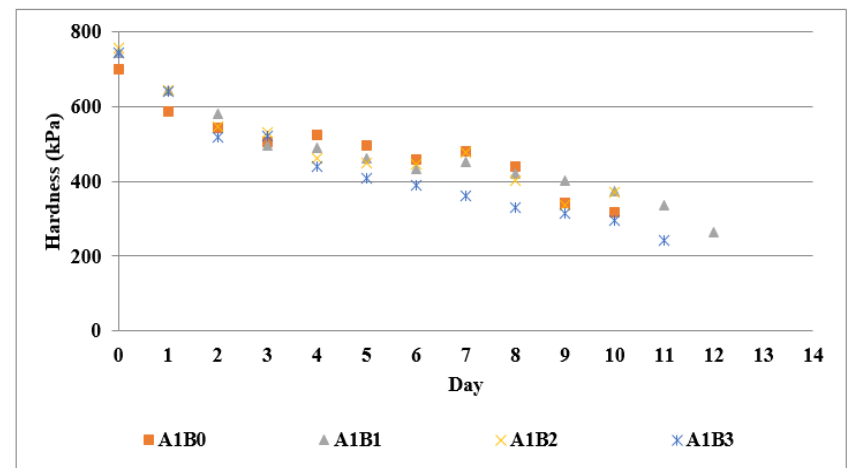

Fig. 4 The Hardness of Zalacca coating at different chitosan concentration and stored at room temperature during storage

Figure 4 shows that the hardness of zalacca without layer decreased largely compared to edible coating. The hardness of zalacca without coating stored at room temperature was $700.718 \mathrm{kPa}$ on day 1 and then decreased to $317.772 \mathrm{kPa}$ on day 10. Zalacca at concentration $1.5 \%$ had the hardness $741.958 \mathrm{kPa}$ and decreased to $240.446 \mathrm{kPa}$ on $11^{\text {th }}$ day. Similar results was shown on fruit coating at $1 \%$ which the value was $756.319 \mathrm{kPa}$ on day 1 and decreased $370.059 \mathrm{kPa}$ on day 10. Zalacca coating at $0.5 \%$ chitosan had the hardness $743.431 \mathrm{kPa}$ and decreased to $262.539 \mathrm{kPa}$. Figure 5 shows that zalacca stored at $15{ }^{0} \mathrm{C}$ suppressed the decreasing the hardness compared to fruit stored at room temperature.

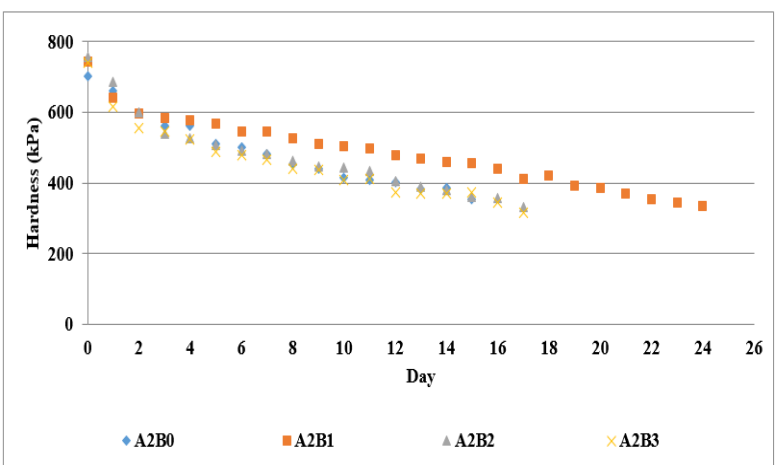

Fig. 5 The hardness of Zalacca coating at different chitosan concentration and stored at $15^{\circ} \mathrm{C}$ during storage.

Zalacca without coating and stored at $15^{\circ} \mathrm{C}$ showed the highest value in decreasing of the hardness. The value was $700.718 \mathrm{kPa}$ on day 1 and decreased to be $353,489 \mathrm{kPa}$ on day 15. Zalacca stored at low temperature and coating with $1.5 \%$ had hardness value around $741.958 \mathrm{kPa}$ on day 1 and decreased to $315.931 \mathrm{kPa}$ on day 27 . Zalacca coating $1 \%$ had the hardness value $753.319 \mathrm{kPa}$ on day 1 and decreased to $332.869 \mathrm{kPa}$ on day 17 . Zalacca coating at $0.5 \%$ and stored at cold temperature maintained the rate of hardness which it could be stored for $24^{\text {th }}$ day. Zalacca coating $0.5 \%$ had the hardness value on day 1 around $743.431 \mathrm{kPa}$ and decreased to $339.919 \mathrm{kPa}$ on the end of storage. Statistical analysis of the hardness of zalacca shows in Table 2.

TABLE II

ANALYSIS OF ANOVA FOR THE HARDNESS OF ZALACCA

\begin{tabular}{|c|c|c|c|c|c|c|}
\hline Source & $\begin{array}{l}\text { Type III } \\
\text { Sum of } \\
\text { Squares }\end{array}$ & df & $\begin{array}{l}\text { Mean } \\
\text { Square }\end{array}$ & $\mathrm{F}$ & Sig. & Conclusion \\
\hline $\begin{array}{l}\text { Concentration of } \\
\text { Chitosan }\end{array}$ & 7043,664 & 3 & 2347,888 & 0,245 & 0,863 & NS \\
\hline Temperature & 467,001 & 1 & 467,001 & 0,049 & 0,828 & NS \\
\hline $\begin{array}{l}\text { Concentration of } \\
\text { Chitosan } \times \\
\text { Temperature }\end{array}$ & 1726,852 & 3 & 575,617 & 0,060 & 0,980 & NS \\
\hline Error & 153169,106 & 16 & 9573,069 & & & \\
\hline Total & 162406,622 & 23 & & & & \\
\hline
\end{tabular}

The results of statistical analysis shows that there not significant difference in concentration of chitosan, which $\mathrm{H}_{0}$ was accepted. It means that the level of concentration was not affect to hardness of zalacca. Similar result was shown in temperature which temperature storage not affect to the hardness of zalacca. Weight loss associated with the fruit ripening also reflects as a progressive decline in flesh firmness [7].

One of the main factors used to determine fruit quality and postharvest shelf life is the rate and extent or firmness loss during the storage of soft fruit, which is attributed to the degradation of cell wall components, mainly pectin's, due to the action of specific enzymes such as polygalacturonase [8]. Fruits are likely to soften mainly due to hydrolysis of the 
pectin acids found in the cell walls, with a consequent loss of fluids [9].

\section{Water content}

Figure 6 shows the water level of zalacca coating at various concentration and stored at room temperature and cold temperature.

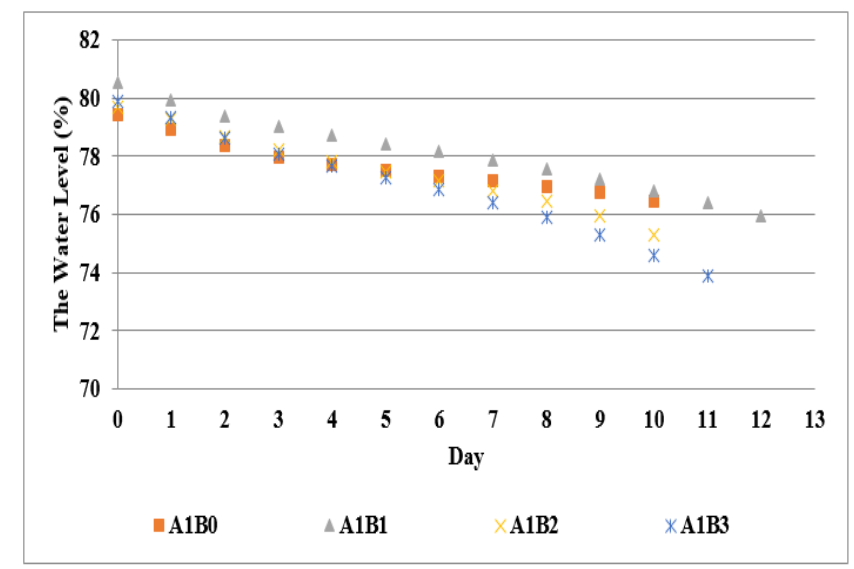

Fig. 6 Water content of Zalacca coating at different chitosan concentration and stored at room temperature

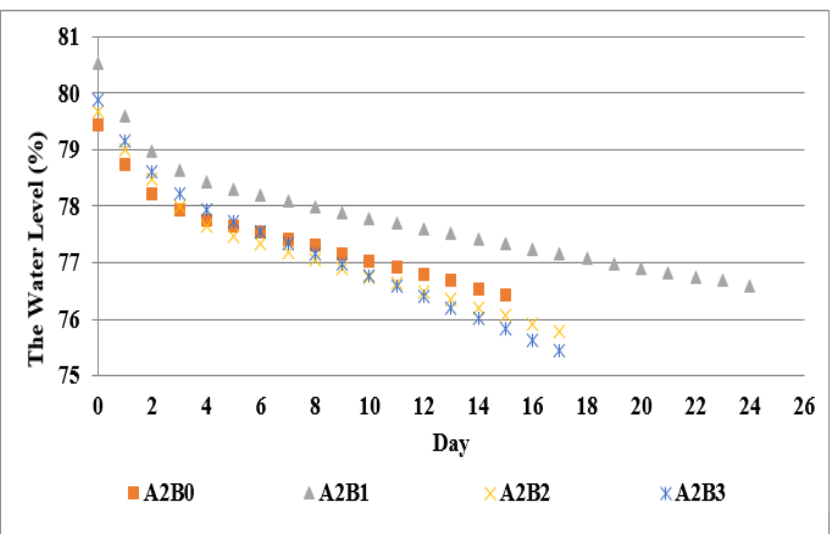

Fig. 7 Water content of zalacca coating at different chitosan concentration and stored at $15^{\circ} \mathrm{C}$

For fruit stored at room temperature, rapid decrease in water content was shown in fruit coating $1.5 \%$ which fruit could be stored until day 11 . While, similar result was shown on fruit coating in $1 \%$ and without coating which fruit could be stored until day 10 , but for fruit at $1 \%$ chitosan rapid decrease in water content occurred in day 8 . On other hand, fruit coating in $0.5 \%$ chitosan can suppressed the decreasing of water content until day 12 . For fruit storage at $15^{\circ} \mathrm{C}$ fruit coating with $1 \%$ and $1.5 \%$ chitosan showed similar trend until the end of storage, while fruit without chitosan only could be stored until day 15 . However, for fruit stored in $0.5 \%$, it could be stored for 24 days.

Based on the Figure 6 shows, the treatment A1B0 0\% and room temperature) had the water content $79.444 \%$ on day 1 , and then decreased to $76,475 \%$ on day 10 . Treatment A1B1 (room temperature, concentration $0,5 \%$ ) the water content was $80.520 \%$ and decreased to $75.973 \%$, which in this condition this treatment, zalacca could be stored for 12 days. Treatment A1B2 (room temperature with concentration 1\%) had water content $79.661 \%$. at the first storage and decreased to $75.280 \%$ on the last day of storage. Treatment
A1B3 (room temperature with concentration 1,5\%) had the content of the water $79.886 \%$ and decreased to $73.901 \%$ at the last storing.

Based on the figure 7, treatment A2B0 (temperature $15^{\circ} \mathrm{C}$ with concentration $0 \%$ ) had water content $79.444 \%$ and decreased to $76.417 \%$ on the last day of storage.. For treatment $\mathrm{A} 2 \mathrm{~B} 1$ (temperature $15^{\circ} \mathrm{C}$ concentration $0,5 \%$ ), water content was $80.520 \%$ and decreased to $76.591 \%$ which zalacca could be stored for 24 days. The treatment A2B2 (temperature $15{ }^{0} \mathrm{C}$, Concentration 1\%) had $79.6615 \%$ and decreased to $75.785 \%$ on day 17. The treatment $\mathrm{A} 2 \mathrm{~B} 3$ (at $15^{\circ} \mathrm{C}$ concentration 1,5\%) had content of the water from $79.886 \%$ and get decreasing to be $75,442 \%$.

Statistical analysis was conducted to investigate influence of temperature and chitosan concentration on the water content of zalacca. The result shows in Table 3.

TABLE III

ANALYSis Of THE WATER CONTENT OF ZALACCA

\begin{tabular}{ccccccc}
\multicolumn{1}{c}{$\begin{array}{c}\text { Type III } \\
\text { Sum of } \\
\text { Source }\end{array}$} & Squares & df & $\begin{array}{c}\text { Mean } \\
\text { Square }\end{array}$ & F & Sig. & Conclusion \\
\hline $\begin{array}{c}\text { Concentration of } \\
\text { Chitosan }\end{array}$ & 2,492 & 3 & 0,831 & 0,654 & 0,592 & NS \\
$\begin{array}{c}\text { Temperature } \\
\text { Concentration of } \\
\text { Chitosan } \times \\
\text { Temperature }\end{array}$ & 0,219 & 1 & 0,219 & 0,172 & 0,684 & NS \\
$\quad$ Error & 20,319 & 3 & 0,113 & 0,089 & 0,965 & NS \\
\hline Total & 23,370 & 23 & 16,270 & & & \\
\hline Explanation : NS $=$ Not Different & & & & & \\
\hline
\end{tabular}

Table 3 shows that the significant value from chitosan concentration 0.592 or $\mathrm{H}_{0}$ was accepted by the level where there was no different on the content of the water of zalacca. Then at the variable of temperature, with its significant values 0.684 or bigger than 0,05 until $\mathrm{H}_{0}$ was accepted means that the storing temperature was not so different with the content of the water.

\section{Total Soluble Solid}

Total of soluble solid is an indirect measurement of fruit sugars, higher - Brix represents more ripe fruit. Figure 8 and 9 shows the total of soluble of zalacca coating at vorius concentration and stored at room temperature and $15^{\circ} \mathrm{C}$.

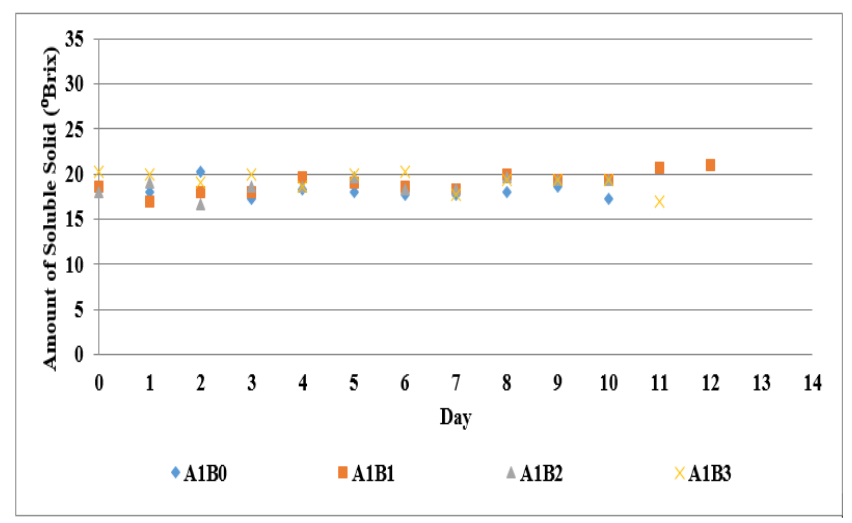

Fig. 8 Total soluble solid of Zalacca coating at different chitosan concentration and stored at room temperature. 


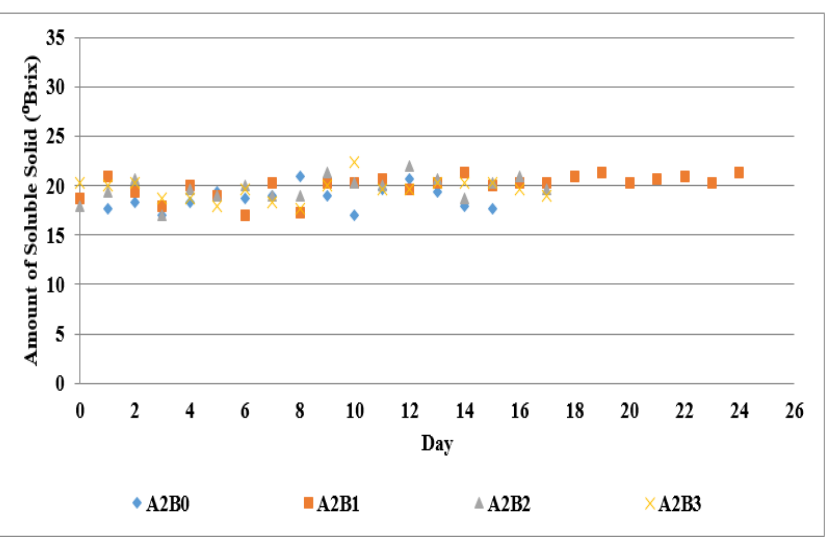

Fig. 9 Total soluble solid of zalacca coating at different chitosan concentration and stored at $15^{0} \mathrm{C}$

From Figure 8 and 9 shows that the total of soluble solid was fluctuate during storage. The decreasing of the soluble solids was caused by respiration process which makes the sugar being reduction to be pyruvates acid and produces $\mathrm{CO}_{2}$ and $\mathrm{H}_{2} \mathrm{O}$. According to Wills et al [11] reported that in the process of ripeness, the solidity is hydrolysed to be sucrose and changed to be a sugar reduction as the substance in the process of respiration. The general prone that occurs during the storage by increasing of sugar content and then it comes to the decreasing. The changing of that sugar follows the patterns of fruit respiration. Therefore, the amount of soluble solid is fluctuate during storage.

Foor fruit stored at room temperature, treatment A1B0 (room temperature, concentration $0 \%$ ) the total was $17^{0} \mathrm{Brix}-$ $20^{\circ} \mathrm{Brix}$ and had shelf life for 10 days. Treatment A1B1 (room temperature, concentration $0.5 \%$ ) the total solid was $16^{0} \mathrm{Brix}-21{ }^{0} \mathrm{Brix}$ and had shelf life for 12 days. For treatment $\mathrm{A} 1 \mathrm{~B} 2$ (room temperature, concentration 1\%) the total of solid was $16^{0} \mathrm{Brix}-19^{0} \mathrm{Brix}$ and had shelf life for 10 days. Treatment A1B3 (room temperature, concentration $1.5 \%$ ) the total was $17^{0}$ Brix $-20^{0}$ Brix and had shelf life for 11 days.

On other hand, for fruit stored at $15^{\circ} \mathrm{C}$, the treatment $\mathrm{A} 2 \mathrm{~B} 0$ (temperature $15^{\circ} \mathrm{C}$, concentration $0 \%$ ) the total was $17^{\circ}$ Brix $-21^{\circ}$ Brix and had shelf life for 15 days. For treatment $\mathrm{A} 2 \mathrm{~B} 1$ (temperature $15^{\circ} \mathrm{C}$, concentration $0,5 \%$ ) the total was $17^{0} \mathrm{Brix}-21^{0} \mathrm{Brix}$ and had shelf life for 24 days. The treatment $\mathrm{A} 2 \mathrm{~B} 2$ (temperature $15^{\circ} \mathrm{C}$, concentration $1 \%$ ) the total of solid was $17^{\circ} \mathrm{Brix}-21^{\circ} \mathrm{Brix}$ and had shelf life for 17 days. At the treatment $\mathrm{A} 2 \mathrm{~B} 3$ (temperature $15^{\circ} \mathrm{C}$, concentration $1,5 \%$ ) the total was $17^{0}$ Brix $-22^{0}$ Brix and had shelf life for 17 days.

From our result, there are differences in total soluble solid of coating zalacca during storage between treated and untreated fruit. Similar result was also found from coating of fresh cut mango which the edible coating had difference in total soluble solid competed with control [10]. Based on our observation the best chitosan concentration to maintain sugar content of zalacca was $0.5 \%$ and $1.5 \%$. The amount of soluble solid was continued with statistics analysis of anova to determine the effect of temperature and chitosan concentration. The result shows in Table 4.
TABLE IV

ANALYSIS VARIAN OF TOTAL SOLUBLE SOLID OF ZALACCA

\begin{tabular}{ccccccc}
\hline \multicolumn{1}{c}{$\begin{array}{c}\text { Type III } \\
\text { Sum of } \\
\text { Source }\end{array}$} & Squares & df & $\begin{array}{c}\text { Mean } \\
\text { Square }\end{array}$ & F & Sig. & Conclusion \\
\hline $\begin{array}{c}\text { Concentration } \\
\text { of Chitosan }\end{array}$ & 4,334 & 3 & 1,445 & 3,416 & 0,043 & $*$ \\
$\begin{array}{c}\text { Temperature } \\
\text { Concentration } \\
\text { of Chitosan } \times\end{array}$ & 3,151 & 1 & 3,151 & 7,451 & 0,015 & $*$ \\
$\begin{array}{c}\text { Temperature } \\
\text { Error }\end{array}$ & 6,766 & 3 & 0,168 & 0,396 & 0,757 & NS \\
\hline Total & 14,753 & 23 & 0,423 & & & \\
\hline Explanation : NS & $=$ Not Different \\
$*$ & $=$ Different as well & & & & & \\
\hline
\end{tabular}

The result in the Table 4 shows that the storage temperature affected to total soluble solid. The best temperature for storage of coating zalacca was $15^{\circ} \mathrm{C}$ because stored at this temperature prolonged the shelf life than stored at room temperature. The result of analysis Duncan of chitosan concentration toward TPT shows in Table 5.

TABLE V

DUNCAN TO DETERMINE EFFECT OF CHITOSAN CONCENTRATION

\begin{tabular}{cccc}
\hline \multirow{2}{*}{$\begin{array}{c}\text { Concentration of } \\
\text { Chitosan }\end{array}$} & $\mathrm{N}$ & \multicolumn{2}{c}{ Subset Alpha $=0,05$} \\
\cline { 3 - 4 } B0 & 6 & 18,44533 & 2 \\
B2 & 6 & 19,22800 & 19,22800 \\
B3 & 6 & & 19,43067 \\
B1 & 6 & & 19,52567 \\
Sig & & 0,053 & 0,464 \\
\hline
\end{tabular}

Based on Table 5 at the column 1 shows that the effect of chitosan concentration to the total of soluble solid $1 \%$ (B2) was not different because it had significant values at 0.053 . At column 2, shows that concentration $1 \%$ (B2), concentration $1.5 \%$ (B3) and concentration $0.5 \%$ (B1) had different values at 0.464 , then it can be concluded that at the colom 2, the highest values was the best way to maintain the total of solidity at zalacca. The best concentration for coating zalacca was $0.5 \%$ (B1) which zalaccas could be stored for 24 days at $15^{\circ} \mathrm{C}$ and 12 days at room temperature.

\section{E. Vitamin C}

The amount of vitamin $\mathrm{C}$ at the fruit can be measured as the total of ascorbat acid. Generally, the content of vitamin C during the storing gets lowering. According to Ministry of Health Republic Indonesia [12], the value of vitamin $\mathrm{C}$ at zalacca at $100 \mathrm{~g}$ is $2 \mathrm{mg}$ or the same as $0,2 \%$.

A graphic about the decreasing of vitamin $\mathrm{C}$ during the storing is shown in figure 10 and 11 .

Based on figure 10 and 11, generally, the value of vitamin $\mathrm{C}$ at zalacca in the first storing at room temperature or $15^{\circ}$ Ctemperature toward the chitosan concentration at each of the treatment until it finished decreased. However, storage at room temperature was faster in decreasing vitamin $\mathrm{C}$ compared to the storing at cold temperature. It was caused by the cold temperature retards the rate of respiration. This condition will cause the change of ascorbate acid to be slowed, then vitamin $\mathrm{C}$ will be easy to get damaged if it gets 
sun ray. The result of observation of vitamin $C$ at zalacca at cold temperature prone to be stable.

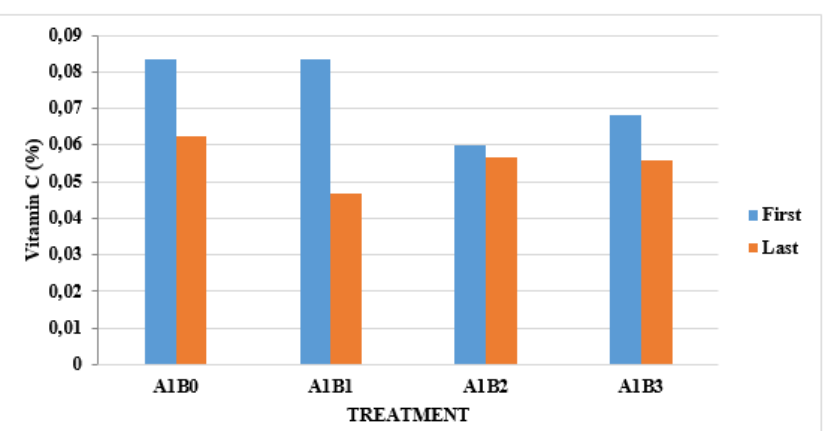

Fig. 10 Vitamin $\mathrm{C}$ of Zalacca coating at different chitosan concentration and stored at room temperature

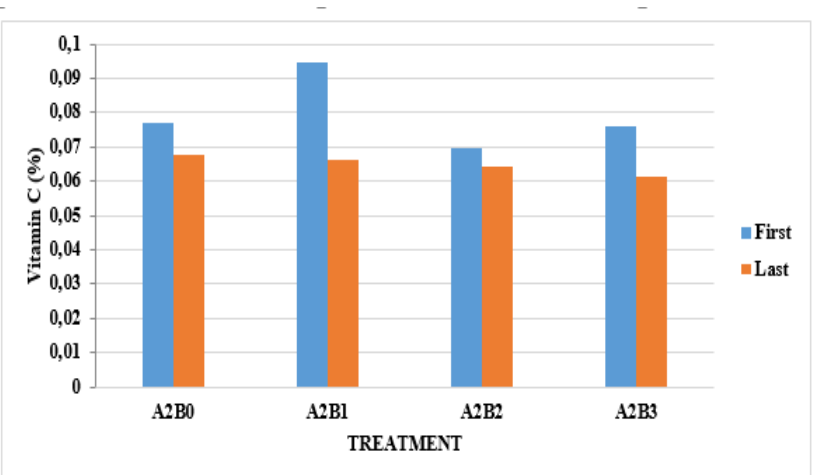

Fig. 11 Vitamin $\mathrm{C}$ of Zalacca coating at different chitosan concentration and stored at $15^{\circ} \mathrm{C}$.

At the treatment A1B0 (room temperature, concentration $0 \%$ ) had the value of vitamin $\mathrm{C}$ at the first storing about $0.083 \%$ and decreased on the end of storage to be $0.062 \%$. At the treatment A1B1 (room temperature, concentration $0,5 \%$ ) had the value of vitamin $\mathrm{C}$ on the first storing about $0.083 \%$ and decreased on the end of storing to be $0.047 \%$.At the treatment A1B1 (room temperature, concentration 1\%) had the value of vitamin $\mathrm{C}$ at the first storing about $0.059 \%$ and decreased at the end of storage to be $0.057 \%$. At the treatment A1B3 (room temperature, concentration 1,5\%) had the value of vitamin $\mathrm{C}$ at the first storing about $0,068 \%$ and decreased at the end of storing to be $0.05 \%$.

At the treatment $\mathrm{A} 2 \mathrm{~B} 0$ (temperature $15^{\circ} \mathrm{C}$, concentration $0 \%$ ) had the value of vitamin $\mathrm{C}$ at the first storing about $0.077 \%$ and decreased at the end of storing to be $0.068 \%$. At the treatment $\mathrm{A} 2 \mathrm{~B} 1$ (temperature $15^{\circ} \mathrm{C}$, concentration $0,5 \%$ ) had the value of vitamin $\mathrm{C}$ at the first storing about $0.095 \%$ decreased at the end of storing to be $0.066 \%$. At the treatment $\mathrm{A} 2 \mathrm{~B} 2$ (temperature $15^{\circ} \mathrm{C}$, concentration $1 \%$ ) had value of vitamin $\mathrm{C}$ at the first storing about $0.069 \%$ and decreased at the end of storing to be $0,064 \%$. At the treatment $\mathrm{A} 2 \mathrm{~B} 3$ (temperature $15^{\circ} \mathrm{C}$, concentration $1,5 \%$ ) had value of vitamin $\mathrm{C}$ at the first storing about $0.076 \%$ and decreased at the end of storing to be $0.061 \%$.

The degree of vitamin $\mathrm{C}$ at room temperature at $15{ }^{\circ} \mathrm{C}$ was lower of chitosan layer at $1 \%$ and $1,5 \%$. It was caused by chitosan layer with concentration can impede the process of respiration at zalacca which affect the damage process of one compound in the fruit. According to Wills et al [11] prone to have a low vitamin $\mathrm{C}$ during storage was caused by organic acid where ascorbate acid had a cracking cell and it becomes the simple compound due to the process of respiration. The result of the observation vitamin $\mathrm{C}$ of zalacca continued with statistic testing of anova analysis to see the influence of temperature and chitosan concentration. The result shows in Table 6.

TABLE VI

ANOVA ANALYSis OF Vitamin C AT ZALACCA DURING ITS STORING

\begin{tabular}{|c|c|c|c|c|c|c|}
\hline Source & $\begin{array}{c}\text { Type } \\
\text { III } \\
\text { Sum of } \\
\text { Squares }\end{array}$ & $\mathrm{df}$ & $\begin{array}{c}\text { Mean } \\
\text { Square }\end{array}$ & $\mathrm{F}$ & Sig. & Conclusion \\
\hline $\begin{array}{l}\text { Concentration of } \\
\text { Chitosan }\end{array}$ & 0,000 & 3 & 0,000 & 0,279 & 0,840 & NS \\
\hline Temperature & 0,001 & 1 & 0,001 & 1,567 & 0,229 & NS \\
\hline $\begin{array}{l}\text { Concentration of } \\
\text { Chitosan } \times \\
\text { Temperature }\end{array}$ & 0,001 & 3 & 0,000 & 0,495 & 0,691 & NS \\
\hline Error & 0,006 & 16 & 0,000 & & & \\
\hline Total & 0,008 & 23 & & & & \\
\hline
\end{tabular}

Based on the Table 6 for the testing of temperature and chitosan concentration influences toward the content of vitamin $\mathrm{C}$ at the fruit shows that the variable at chitosan concentration had significant value about 0.840 and it indicated that $\mathrm{H}_{0}$ was accepted and it means that the chitosan concentration was not different toward vitamin $\mathrm{C}$ and the damaged of zalacca. The variable of temperature had a significant value about 0.229 or bigger than 0.05 or $\mathrm{H}_{0}$ was accepted and it means that the stored temperature was not different toward vitamin $\mathrm{C}$ at the damaged of zalacca.

\section{F. Organoleptic Experiment}

Organoleptic testing for 10 panellists were aroma, texture, color and taste at each of the treatment. Organoleptic testing was conducted by storage the fruit until cannot consume. The assessment had range from 1-5 with 1(very dislike), 2 (dislike), 3(so-so), 4 (like), and 5 (very like). The result of the assessment of all panellists was averaged where the average was 4.50-5.00 means very like 3.50-4.49, like 2.603.49 , so-so 1.60-2.50, and dislike 1.00-1.50. The color of the skin was one of the parameters to decide before buying. The skin color at zalacca was browning yellow with brightness at the pole. The colour that liked by panellists was a brightness of fruit, no wrinkle and there was no black spot of damaging.

The result of organoleptic toward skin color during the storage shows in figure 12 and 13.

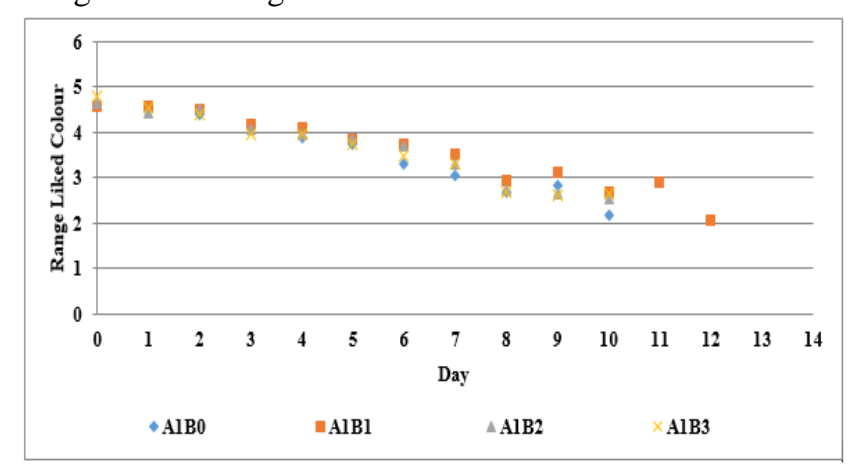

Fig. 12. The Level of panelist' fondness to the color of Zalacca coating at different chitosan concentration and stored at room temperature 


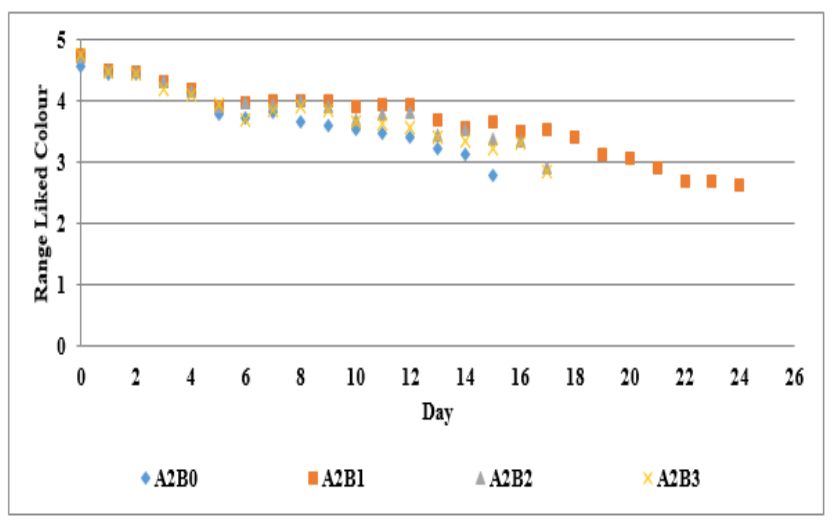

Fig. 13. The Level of panelist' fondness to the color of zalacca coating at different chitosan concentration and stored at $15^{\circ} \mathrm{C}$

Based on the Figure 12 shows that the level of fondness toward the color at room temperature at the first day until the $6^{\text {th }}$ day still liked by the panellists. It can be seen at the value 4-5 which means that the color still be liked as well. At the $7^{\text {th }}$ day, the level of panellist' fondness toward the color decreased about 3-3.5 that means that they did not like it. At room temperature, the panellist' fondness for the color decreased where zalacca without chitosan layer $1.5 \%$ and $1 \%$. It shows that the lowest value of decreasing came from chitosan $0.5 \%$.

The value of panellist fondness for the color at cold temperature was decreased. In figure 13, it shown that at the first day until $11^{\text {th }}$ the panellists still like the color and then did not come the next day. The level of fondness was significant on the treatment without chitosan layer, then $1,5 \%$ and $1 \%$. The smallest treatment of layer decreased in the color. It was shown on the $13^{\text {th }}$ day at the value 4 .

The shrinking of fruit influenced the color of zalacca. It was caused by respiration, the shrinking fruit that occurred on the fruit. The damaged of zalacca' skin was indicated with the growing of white mold, then it could not be consumed. The damaged of the skin at $15^{\circ} \mathrm{C}$ was indicated by the crack and the wrinkle of the skin as showed in the figure 14 .

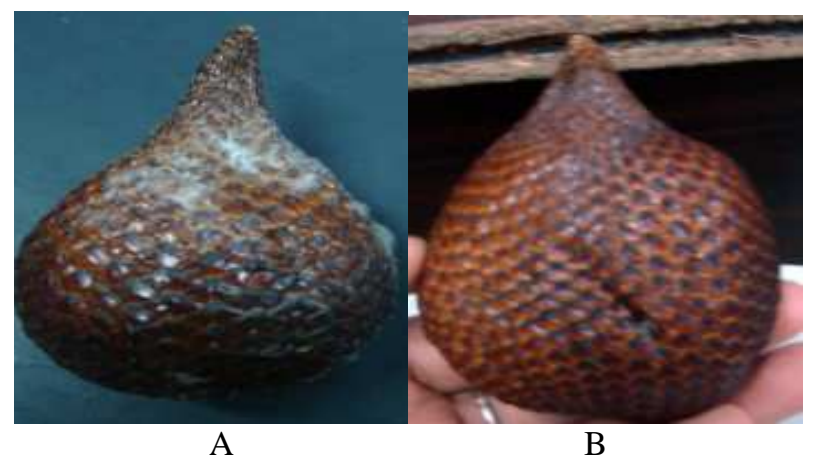

Fig. 14 (A) Zalacca' Skin at Room Temperature, (B) Zalacca' Skin at $15^{\circ} \mathrm{C}$ Temperature

The color, aroma, zalacca also was evaluated by organoleptic. From aroma the quality of fruit could be determined. The charismatic aroma of zalacca without other aroma was like by panellist. The values of panellist' fondness toward the aroma of zalacca in each day was decreased. The decreasing shows in the figure 15 and 16.

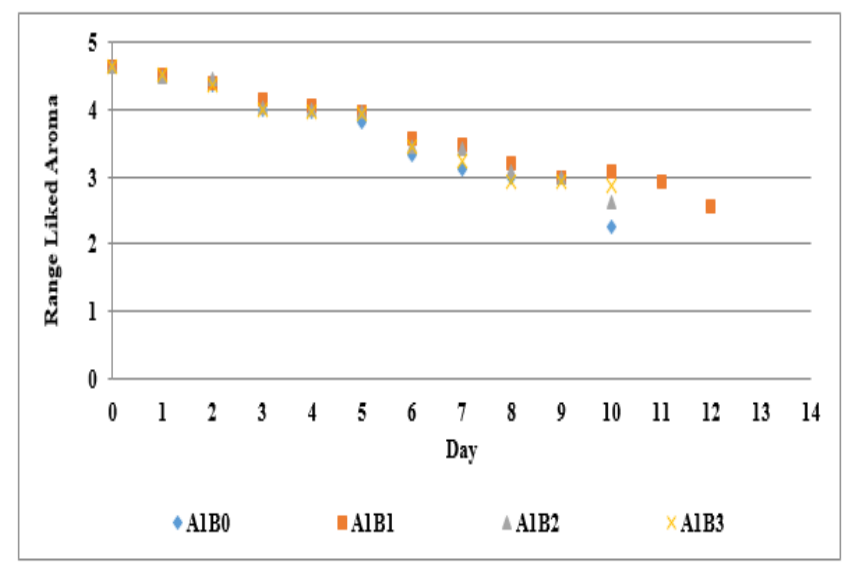

Fig. 15. A graphic of Panelist' Fondness to the Aroma of Zalacca coating at different chitosan concentration and stored at room temperature

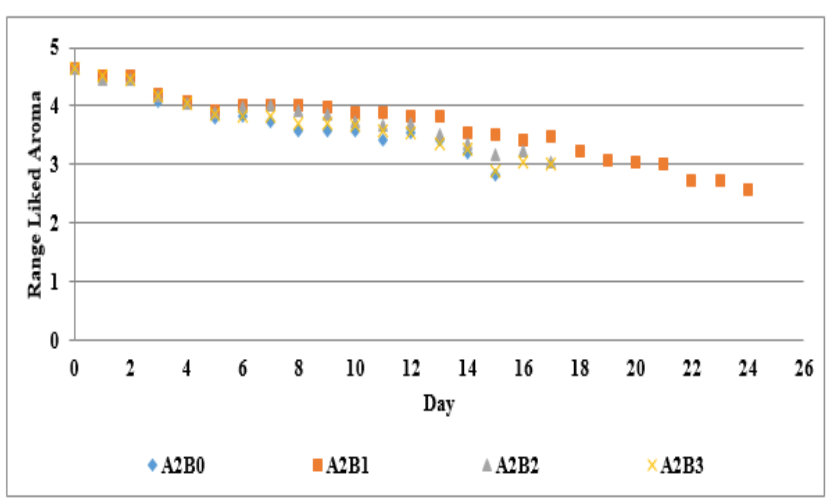

Fig. 16. A Graphic of Panelist'Fondness to the Aroma of of zalacca coating at different chitosan concentration and stored at $15^{\circ} \mathrm{C}$.

Based on the figure 15 shows that the room temperature had values on panellist fondness on the aroma of zalacca where fruit could be stored until 6 days for each treatment. The highest decreasing value of the level of aroma fondness was found on zalacca without the treatment about 2.27. While at chitosan layer $1.5 \%$ and $1 \%$ decreased of aroma fondness on the $10^{\text {th }}$. At $1 \%$ chitosan the value was about 2.63 meanwhile at $1.5 \%$ was about $2.87 \%$. Chitosan layer $0.5 \%$ at the first storage had aroma about 4.63 and at the end of storage had 2.57 and extended the self life for 12 days.

The level of panellist fondness toward the aroma of zalacca at cold temperature shows in figure 16 . At the $20^{\text {th }}$ days until $14^{\text {th }}$, the panellist was like the aroma. The significant value of decreasing of aroma was on the treatment without chitosan layer, then at $1.5 \%$ and $1 \%$ chitosan. From the graph, the treatment of chitosan layer $0,5 \%$ slightly decreased of the aroma. It was shown at the treatment of panellist fondness which exists on $14^{\text {th }}$ in 3,9 had shelf life for 24 days.

The texture was also assessed in organoleptic test. The texture affected the quality. For long storage, the zalacca had the bad of the quality and continued to damaged which had soft texture and flesh produced the water. The hard texture indicates that the fruit could be consumed. The decreasing of its texture was shown in figure 17 and 18. 


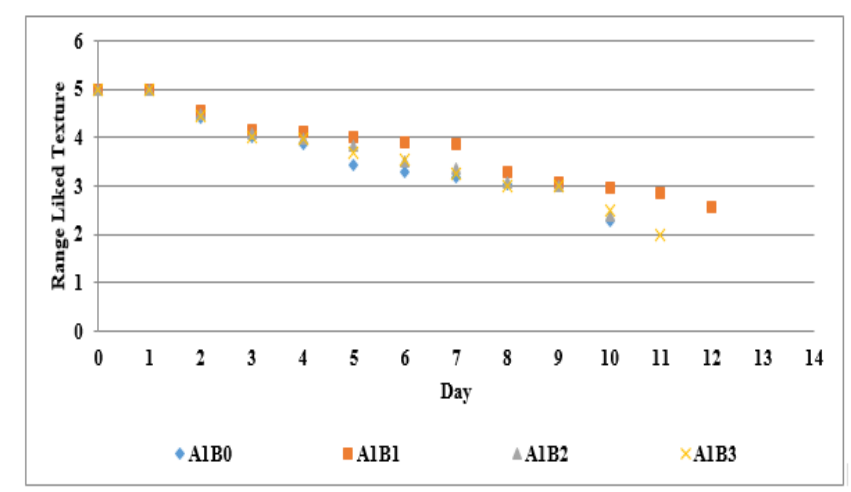

Fig. 17. A Graphic of the level of panelist' fondness to texture of zalacca coating at different chitosan concentration and stored at room temperature

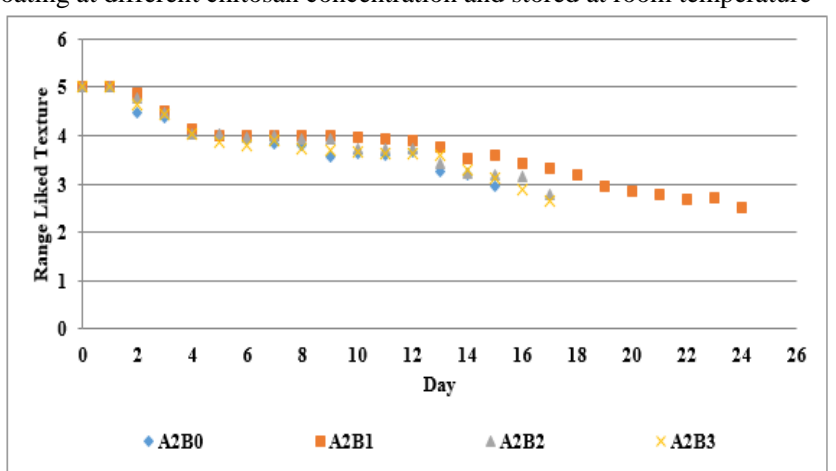

Fig. 18. A Graphic of the panelist' pondness to the texture of of zalacca coating at different chitosan concentration and stored at $15^{\circ} \mathrm{C}$.

Based on figure 17 and 18 it can be seen that the texture of zalacca has decreasing with its long storing. The decreasing happened at room storing and cold area. The values of fondness of zalacca texture at the first day until $7^{\text {th }}$ day still are liked by the panellist with the value 4 and 5 . The significant decreasing of the fondness toward the texture will happen at the treatment without chitosan layer and has a life storing during 10 days. The decreasing of the fondness toward the texture also happened at $1,5 \%$ and $1 \%$ layer meanwhile at $0,5 \%$ it has a small decreasing which can maintain during 12 days. The level of panellist' fondness toward the texture also gets decreasing. At the first day until $14^{\text {th }}$, the panellist still likes the texture of zalacca.

However, for the next day, the level of fondness which gets decreasing comes to be 'like'. The significant level of fondness which gets decreasing is at the treatment without chitosan and at $1,5 \%$ and $1 \%$ layer. If we see at the graphic, the treatment of chitosan layer $0,5 \%$ has decreasing of the texture, it can be seen at the treatment where the value of panellist fondness maintains at $14^{\text {th }}$ day is at 3,9 and has a life storing during 24 days. The decreasing of panellist' fondness is caused by the crispy of the fruit. The softness of the fruit is caused by the cracking of proto pectin which become pectin which is soluble in the water or it happens due to the hydrolysis, fat, or lignin [13]. The decreasing of its texture is also caused by the process of transpiration which loose its water and it can be seen at the shrink of the fruit and the wrinkle of its texture.

Taste is one of the parameter which affects the acceptance of consumer toward the product. The taste of zalacca is dominated by the mixing of sugar and acid. A graphic of panellist' fondness toward the taste of zalacca can be seen at figure 19 and 20.

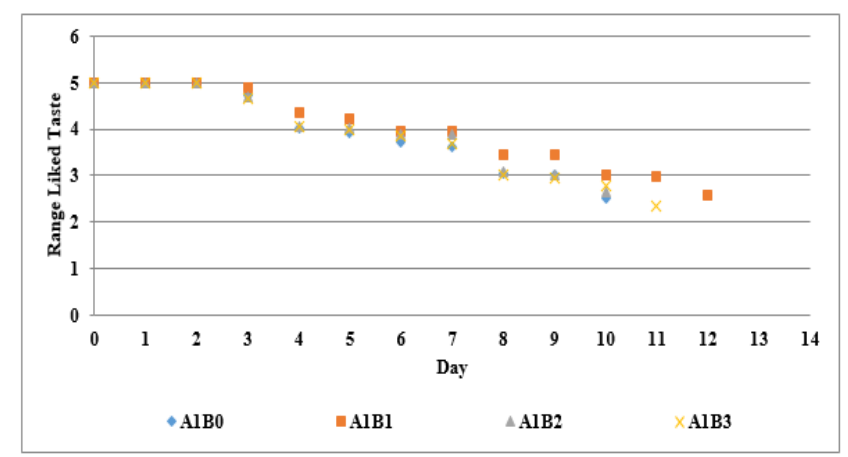

Fig. 19. A Graphic of panelist' fondness to taste of zalacca coating at different chitosan concentration and stored at room temperature

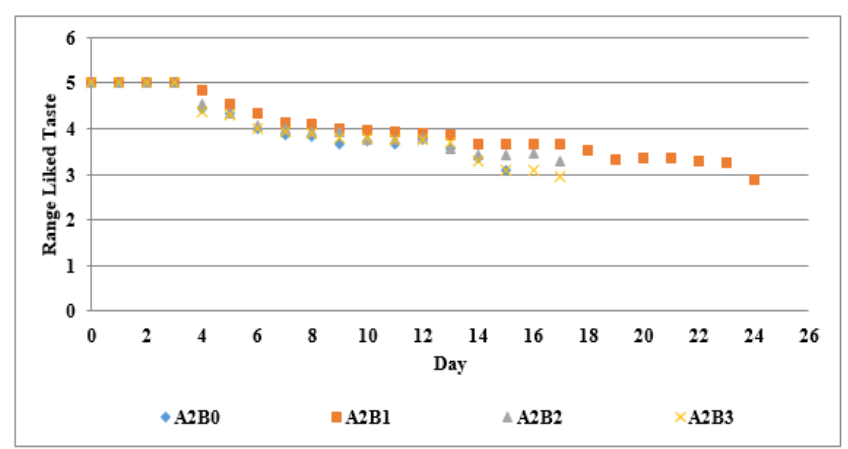

Fig. 20.AGraphic of panelist' pondness to taste of of zalacca coating at different chitosan concentration and stored at $15^{\circ} \mathrm{C}$.

Based on the figure 19 shows that the room temperature storage of zalacca was accepted on the $8^{\text {th }}$ day. For the next day, the taste value decreased by the panellists. The significant value decreased quality for the treatment without layer then came from chitosan $1.5 \%$ and $1 \%$. Chitosan veneering $0.5 \%$ had small value, it shows that it could maintain the quality of the fruits until it was stored on the $12^{\text {th }}$ day. Based on figure 21 , show that the storage of zalacca at cold temperature did not decrease the quality of zalacca. Chitosan veneering $0.5 \%$ maintained quality until $14^{\text {th }}$ day which had value $4-5$. Then for the next day, the level of panellist's fondness decreased about 3-3.8. At layer concentration $0.5 \%$, zalacca had a long life during 24 day. And without its layer, it only maintained until $9^{\text {th }}$ day.

Based on the observation, the value of fondness decreased day by day. This was caused by the content of the water in the fruit, then the lowering chemical substance like vitamin $\mathrm{C}$ and sugar during the storing. The taste of zalacca was influenced by the amount of solid solubility, amount of acid, and other compounds from the process of metabolism.

The lowering level of panellist fondness toward the taste of zalacca was caused by the tasteless and a bit of sour taste of zalacca. An insipid taste was caused by the amount of acid in the fruit where its sweetness being low.

\section{CONCLUSIONS}

Based on the result of the research, we concluded: Concentration of chitosan affects to total of soluble solid of zalacca, but it did affect to weight loss, hardness, content of the water, and vitamin C. Storage temperature influenced the total of soluble solid in zalacca, but it did not affect to weight loss, hardness, content of the water, and vitamin C. 
The best concentration of chitosan was at $0.5 \%$ which stored at $15^{\circ} \mathrm{C}$ of room temperature because on this condition can extend the shelf life of fruit for 24 days. Zalacca without coating had a short shelf-life time around 15 days stored at the temperature $15^{\circ} \mathrm{C}$ and 10 days at room temperature.

\section{REFERENCES}

[1] Badan Pusat Statistik Provinsi Sumatera Barat. 2013. Kabupaten Pasaman Barat dalam Angka 2013. Padang.

[2] Titiek, F. D. dan Mudjisihono, R. 1998. Perubahan Sifat Fisik dan Kimia Buah Salak Pondoh pada Berbagai Perlakuan Penyimpanan Buah Segar. Buletin Agro Industri No. 05, Jakarta.

[3] Hassanpour, H. (2015). Effect of Aloe vera gel coating on antioxidant capacity, antioxidant enzyme activities and decay in raspberry fruit. LWT _ Food Science and Technology, 60(1), 495501.

[4] Guerreiro, A.C,. Gago, C.M.L, Miguel, M.G.C,. Faleiro, M.L Antunes,M.D.C. 2016. The influence of edible coatings enriched with citral and eugenol on the raspberry storage ability, nutritional and sensory quality. Food Packaging and Shelf Life 9, 20-28.

[5] Rachmawati, M. 2004. Pelapisan Chitosan pada Buah Salak Pondoh (Salaccaedulis Reinw.) sebagai Upaya Memperpanjang Umur Simpan dan Kajian Sifat Fisiknya selama Penyimpanan. [Tesis]. Yogyakarta: Ilmu dan Teknologi Pangan. Universitas Gadjah Mada.
[6] Krochta, J. M., \& De Mulder-Johnston, C. (1997). Edible and biodegradable polymer films: Challenges and opportunities. Food Technology, 51(2), 61-74.

[7] Forato, L.A., Douglas de Britto, de Rizzo, J.S., Gastaldi, T.A., Assis, O.B.G,. 2005. Effect of cashew gum-carboxymethylcellulose edible coatings in extending the shelf-life of fresh and cut guavas. Food Packaging and Shelf Life 5, 68-74.

[8] Tanada-Palmu, P. S., \& Grosso, C. R. F. (2005). Effect of edible wheat gluten-based films and coatings on refrigerated strawberry (Fragaria ananassa) quality. Postharvest Biology and Technology, 36(2), 199-208. http://dx.doi.org/10.1016/j. postharvbio.2004.12.003.

[9] Tapia, M., Rojas-Graü, M., Carmona Rodríguez, J., Soliva-Fortuny, R., \& Martin- Belloso, O. (2008). use of Alginate- and gellan-based coatings for improving barrier, texture and nutritional properties of fresh-cut papaya. Food Hydrocol- loids, 22, 1493-1503.

[10] Salinas-Roca, B., Soliva-Fortuny,R., Welti-Chanes, J., MartínBelloso, O. 2016. Combined effect of pulsed light, edible coating and malic acid dipping to improve fresh-cut mango safety and quality. Food Control 66, 190-197.

[11] Wills RH, Lee TH, Graham WB, Glasson, Hall EG. 1981 Post-Harvest, an Introduction to The Phisiology and Handling of Fruit and Vegetables. Hongkong: South China Printing Co.

[12] Direktorat Gizi Departemen Kesehatan RI. 1981. Daftar Komposisi Bahan Makanan. Jakarta: BharataKarya Aksara.

[13] Pantastico, Er. B. 1986. Fisiologi Pascapanen Penanganan dan Pemanfaatan Buah-Buahan dan Sayur-Sayuran Tropika dan Subtropika. Diterjemahkan oleh Kamariyani dan Tjitrosoepomo, G. Yogyakarta : Gadjah Mada University Press 